\title{
Penerapan Aplikasi Kasir Portabel pada Kedai Sari Kopi Banjarbaru
}

\author{
Application of Portable Cashier Softwareat Kedai Sari Kopi Banjarbaru
}

\author{
Fathul Hafidh ${ }^{1}$, Rezky Izzatul Y.A ${ }^{1}$, Nur Arminarahmah ${ }^{{ }^{*}}$ \\ 1 Teknik Informatika,Universitas Islam Kalimantan MAB Banjarmasin \\ *nur.armina@gmail.com
}

\begin{abstract}
ABSTRAK
Kasir adalah tempat melakukan transaksi atau pembayaran yang menjadi akhir dari sebuah transaksi jual beli antara konsumen dan produsen sehingga menghasilkan kepuasan pada masing-masing pihak. PenerapanPoint of Sales pada aplikasi kasir portabel ini sebagai orientasi sistem penjualan yang akan membantu proses transaksi penjualan dan stok barang. Kedai Sari Kopi memiliki menu minuman dan makanan dimana minuman utama yang disuguhkan adalah kopi, kendala yang dihadapi antara kasir dan karyawan dapur adalah jarak yang cukup jauh mengakibatkan terkendala untuk proses pemesanan secara cepat antara kasir dan karyawan dapur berdasarkan permasalahan diusulkanlah pengabdian masyarakat berupa pelatihan aplikasi (software) kasir portabel untuk membantu peningkatan pelayanan kedai sari kopi dan terpadunya laporan administrasi untuk pelaporan rugi laba sebagai bahan evaluasi untuk kedai sari kopi Banjarbaru.
\end{abstract}

Kata kunci — kasir, kedai sari kopi, point of sales, portabel

\section{ABSTRACT}

The cashier is a place to make transactions or payments that become the end of a buying and selling transaction between consumers and producers so as to produce satisfaction for each party. The application of Point of Sales in this portable cashier application is an orientation of the sales system that will help process sales transactions and stock goods. Kedai Sari Kopi has a drink and food menu where the main drink served is coffee, the obstacle faced between the cashier and the kitchen employees is that the distance is quite far resulting in constraints for the quick ordering process between the cashier and the kitchen employee. portable to help improve coffee shop services and integrated administrative reports for profit and loss reporting as evaluation material for Banjarbaru Sari coffee shops.

Keywords - cashier, coffee shop, point of sales, portable 


\section{Pendahuluan}

Sistem mesin kasir atau lebih dikenal denganpoint of sale (POS) merupakan aktivitas yang berorientasi pada penjualan serta sistem yang membantu proses transaksi penjualan dan stok barang.

Kedai sari kopi merupakan usaha binaan milik karang taruna "Pemuda Tjahaya" yang bergerak dibidang usaha penjualan kopi dari berbagai jenis kopi dan kudapan. Transaksi yang selama ini berjalan masih menggunakan sistem manual sehingga rentan akan human error karena tidak terpadu di dalam aplikasi.

Sistem kasir pada kedai sari kopi yang digunakan saat ini masih menggunakan sistem manual dan jarak antar karyawan yaitu karyawan pada bagian dapur cukup jauh mengakibatkan rentan terjadi kesalahan pesanan dari bagian karyawan pemesanan ke bagian karyawan bagian dapur.

Manfaat dari diterapkannya aplikasi kasir ini adalah adanya peningkatan pelayanan dan memudahkan di dalam proses pelaporan rugi laba dan memudahkan proses pelayanan karena aplikasi kasir terkoneksi langsung ke bagian dapur dan pada aplikasi kedai sari kopi menghasilkan report penjualan yang berfungsi sebagai nota pembelian untuk diserahkan langsung ke pembeli.

Berdasarkan uraian permasalahan di atas maka diperlukannya penerapan aplikasi kasir untuk mendukung proses transaksi yang membantu untuk peningkatan pelayanan dan sistem administrasi yang lebih terpadu sehingga dapat meningkatkan pelayanan dalam penjualan, pelaporan rugi laba lebih mudah karena sudah terpadu di dalam aplikasi kasir.

\section{Target dan Luaran}

Permasalahan pada mitra pengabdian yaitu belum terpadunya di dalam aplikasi sehingga tim pengabdian akan membantu dengan memberikan solusi terhadap masalah yang dihadapi berupa pelatihan aplikasi kasir portabel kepada kasir dan karyawan.

Proses transaksi penjualan yang berjalan di mitra pengabdian yaitu Kedai Sari Kopi masih bersifat manual dengan mengkalkukasi semua pembelian kemudian ditulis pada nota pembayaran sehingga diperlukan suatu aplikasi kasir portabel untuk membantu proses transaksi serta proses pelaporan rugi laba yang mudah digunakan dan bisa diaplikasikan pada perangkat apa saja misalkan smartphone dan personal computer (PC) maupun Laptop.

Solusi permasalahan yang akan diberikan adalah dengan memberikan pelatihan untuk penerapan aplikasi kasir portabel kepada kasir serta karyawan pada mitra pengabdian yaitu pada Kedai Sari Kopi Banjarbaru sehingga dapat mendukung peningkatan pelayanan kepada pengunjung kedai sari kopi Banjarbaru.

Peserta dari kegiatan pengabdian masyarakat ini adalah sejumlah 10 orang yaitu terdiri dari 2 orang kasir dan 8 orang karyawan ,kegiatan berlangsung dari 4 Desember 2018 - 30 Maret 2019 dan tempat pelatihan di Kedai Sari Kopi Banjarbaru.

Tabel 1. Target Luaran

\begin{tabular}{|l|l|l|}
\hline No & Jenis Luaran & $\begin{array}{l}\text { Indikator } \\
\text { Capaian }\end{array}$ \\
\hline 1 & $\begin{array}{l}\text { Publikasi ilmiah pada Jurnal } \\
\text { ber ISSN/Prosiding }\end{array}$ & Accepted \\
\hline 2 & $\begin{array}{l}\text { Publikasi pada media masa } \\
\text { cetak/ online/ repocitory PT }\end{array}$ & draft \\
\hline 3 & $\begin{array}{l}\text { Peningkatan daya saing } \\
\text { (peningkatan kualitas, } \\
\text { kuantitas, serta nilai tambah } \\
\text { barang, jasa, diversifikasi } \\
\text { produk, atau sumber daya } \\
\text { lainnya ) }\end{array}$ & Produk \\
\hline 4 & $\begin{array}{l}\text { Peningkatan penerapan iptek } \\
\text { di masyarakat (mekanisasi, } \\
\text { IT, dan manajemen) }\end{array}$ & Penerapan \\
\hline 5 & $\begin{array}{l}\text { Perbaikan tata nilai } \\
\text { masyarakat (seni budaya, } \\
\text { sosial, politik, keamanan, } \\
\text { ketentraman, pendidikan, } \\
\text { kesehatan }\end{array}$ & $\begin{array}{l}\text { Sudah } \\
\text { dilaksanakan }\end{array}$ \\
\hline
\end{tabular}

Target dari pelaksanaan pengabdian ini adalah peserta yaitu kasir dan karyawan mampu memahami penggunaan aplikasi kasir portabel sehingga dapat bermanfaat dan meningkatkan efektivitas serta pelayanan di kedai sari kopi, pengadaan perangkat point of saledan printer kasir. Luaran yang dihasilkan adalah kemampuan menggunakan aplikasi kasir portabel dengan baik dan sesuai dengan format 
yang dirancang. Penilaian kemampuan diukur dari evaluasi saat peserta pengabdian melakukan uji coba aplikasi kasir. Capaian luaran dalam program pengabdian ini dijelaskan di Tabel 1.

\section{Metodologi}

Metode pelaksanaan kegiatan pengabdian kepada masyarakat ini yaitu :

\subsection{Pelatihan}

Proses pengenalan melalui pelatihan dilaksanakan di kedai sari kopi ,dengan melatih kasir serta karyawan untuk menggunakan aplikasi sehingga pada saat implementasi aplikasi kasir sudah mengetahui proses penggunaan dan cara kerja aplikasi sampai dengan menghasilkan nota pembayaran.

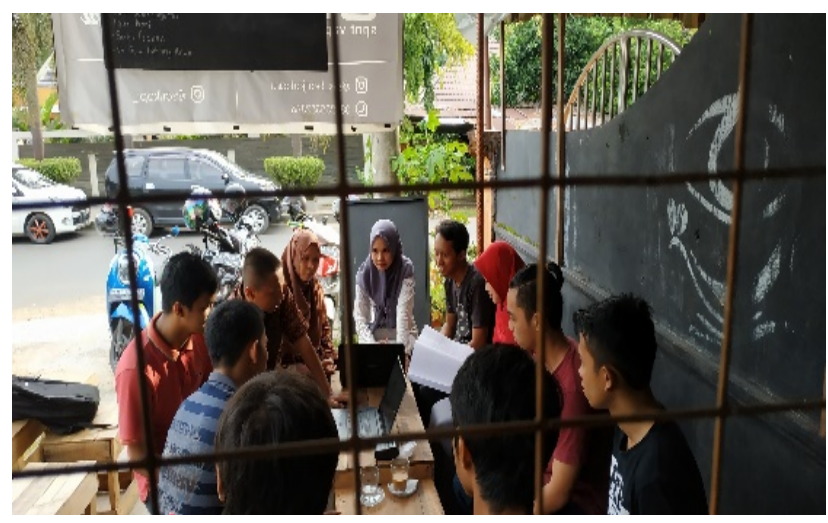

Gambar 1. Proses Pelatihan

\subsection{Instalasi}

Tahapan ini adalah proses instalasi aplikasi kasir dan dilakukan oleh tim pengabdian serta disaksikan oleh kasir sehingga kasir memahami proses instalasi aplikasi kasir.

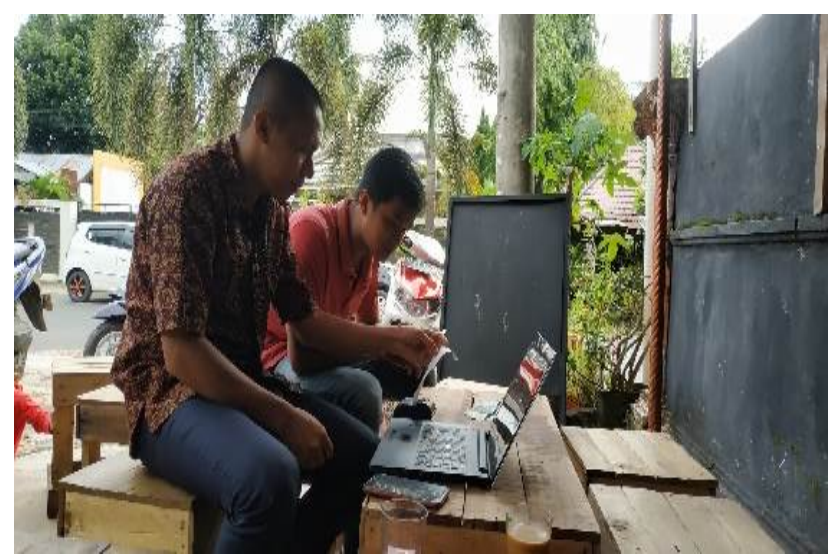

Gambar 2. Proses Instalasi Aplikasi

\subsection{Testing aplikasi}

Uji coba aplikasi bertujuan untuk mengetahui kesiapan kasir dan karyawan dalam memahami cara penggunaan serta cara kerja aplikasi kasir sehingga saat implementasi di tahapan transaksi dan pelaporan rugi laba tidak mengalami kendala.

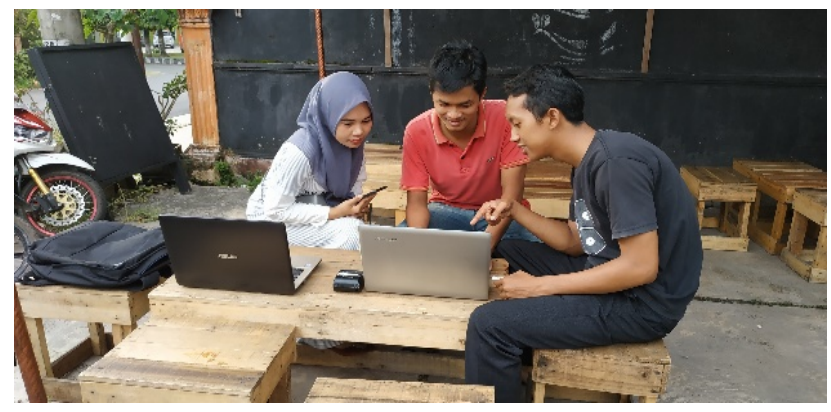

Gambar 3. Uji coba Aplikasi Oleh Kedai Sari Kopi

\subsection{Monitoring dan Evaluasi}

Monitoring aplikasi untuk mengetahui kesalahan - kesalahan yang terjadi pada aplikasi sehingga dapat disempurnakan menjadi aplikasi kasir yang memiliki menu serta fungsi yang mendukung peningkatan pelayanan di kedai sari kopi.

Evaluasi bertujuan untuk mengukur tingkat kemudahan aplikasi agar pengguna dapat dengan mudah menggunakan aplikasi kasir dan dapat menyelesaikan permasalahan (troubleshooting) sendiri tanpa selalu di dukung oleh rekanan.

\section{Pembahasan}

Aplikasi kasir portabel dengan tampilan awal daftar menu dan kudapan yang tersedia di Kedai Sari Kopi Banjarbaru, kasir tinggal memilih menu pilihan di menu dan daftar menu yang di pilih kasir akan muncul pada perangkat di bagian dapur sehingga distribusi pesanan dapat dikerjakan dengan cepat oleh karyawan dapur. 


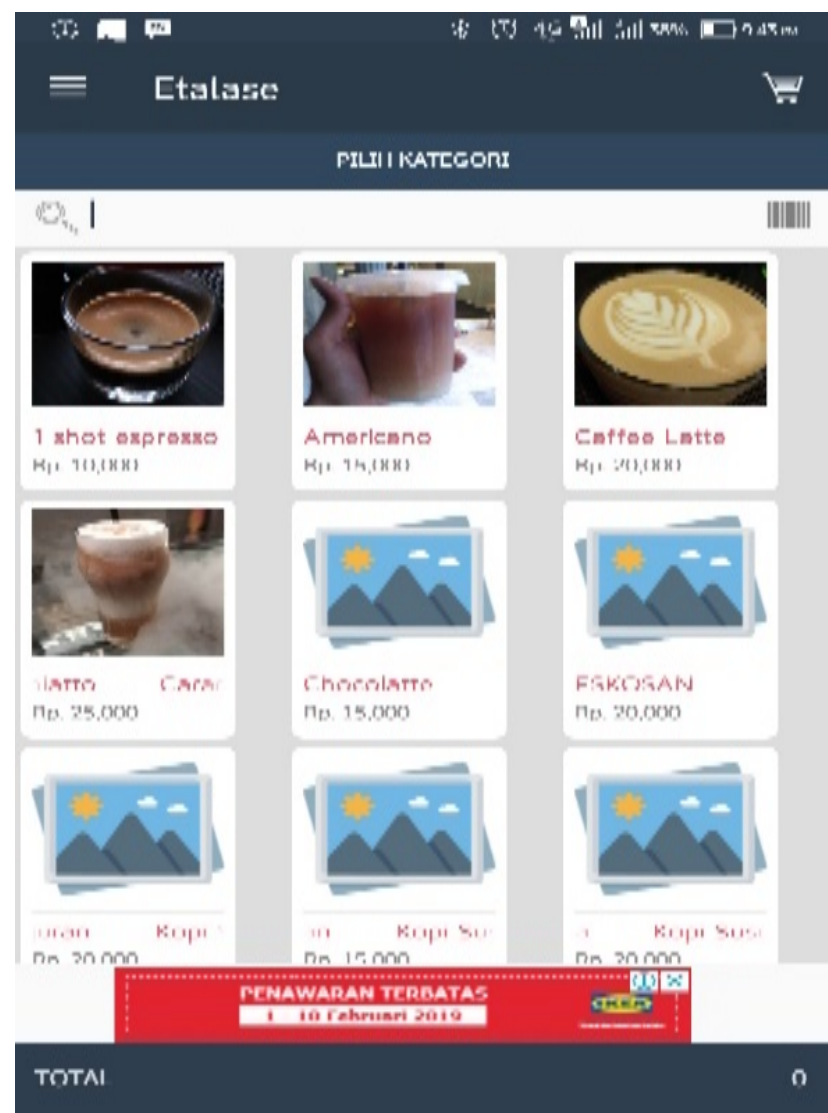

Gambar 4. Halaman Etalase Menu

Proses berikutnya adalah perhitungan pembayaran untuk menghasilkan nota penjualan sebagai bentuk keluaran dari aplikasi kasir portabel ini.

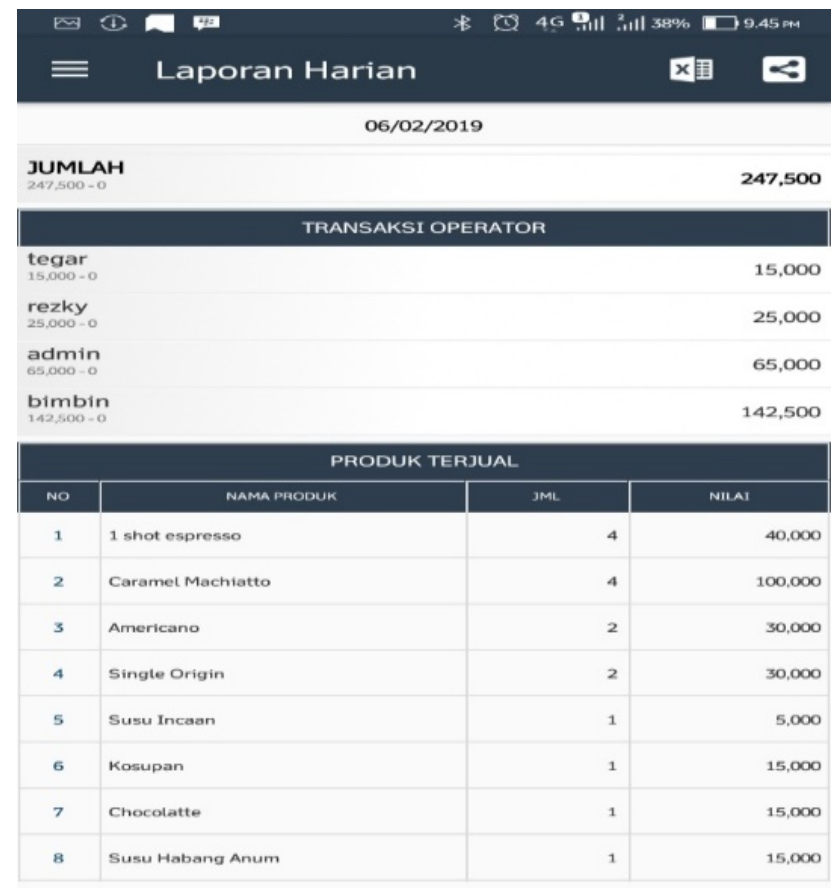

Gambar 5. Halaman Input Pembayaran

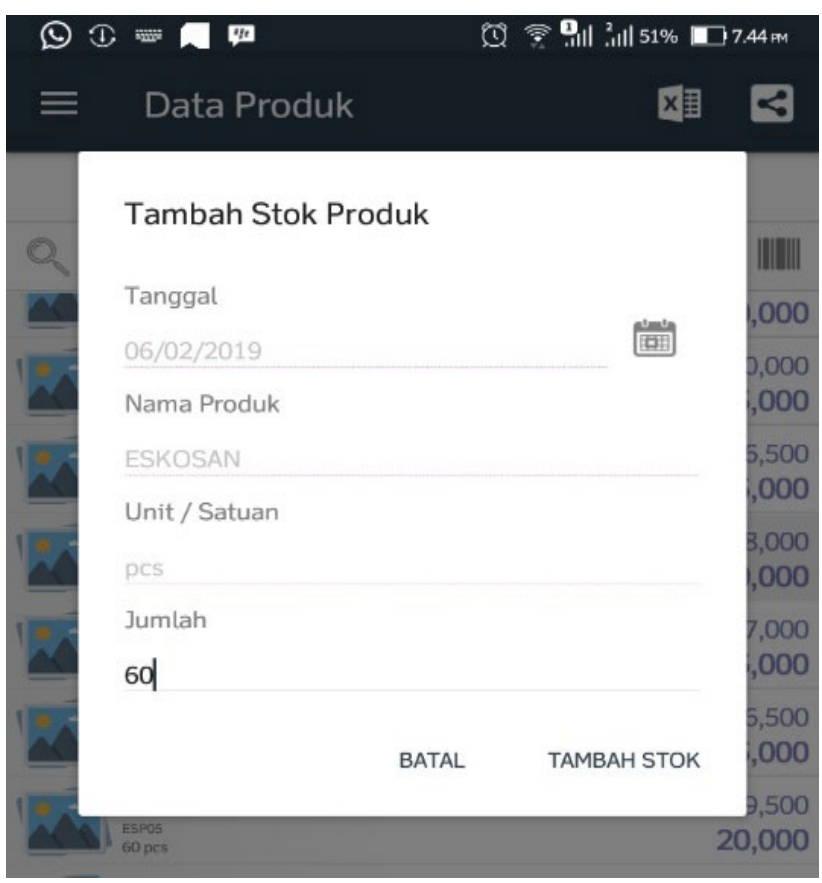

Gambar 6. Tampilan Total Pembelian

Proses stok barang pada kedai juga tersedia pada aplikasi kasir portabel ini, dengan memasukkan jumlah barang yang masuk dan nama barang yang masuk

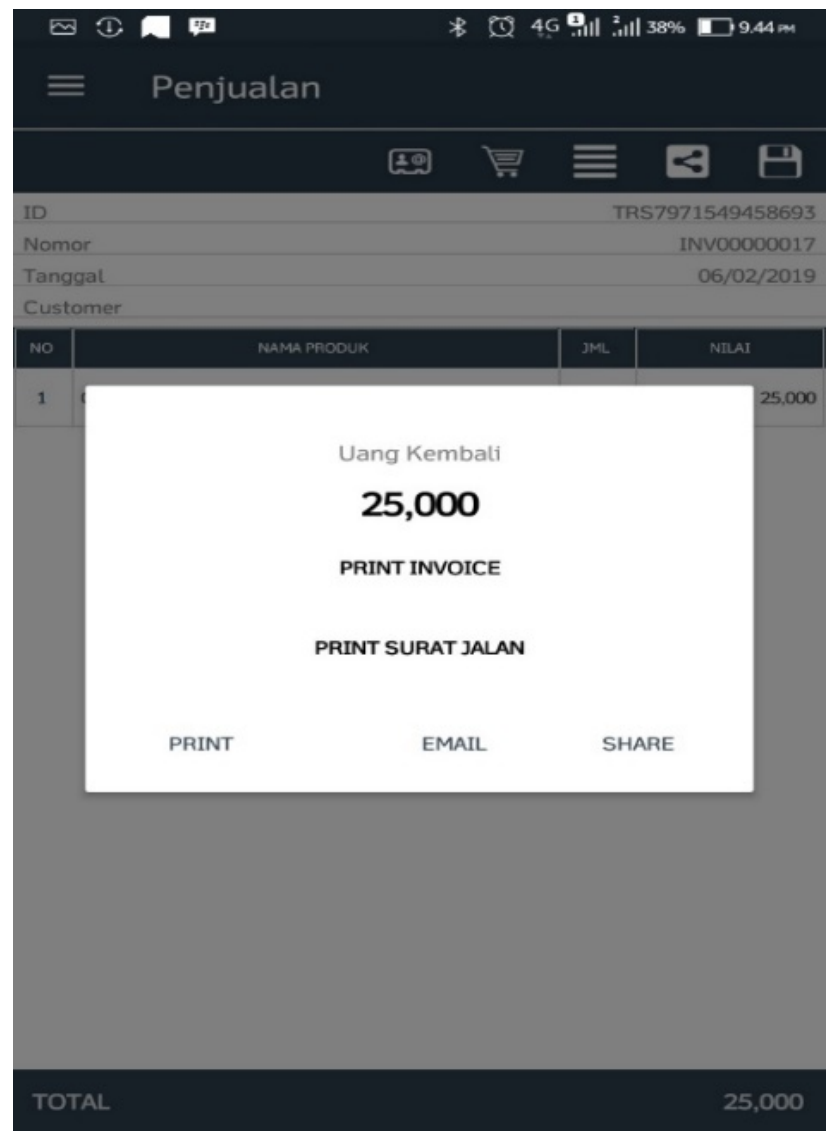

Gambar 7. Halaman Tambah Stok 
Manfaat dari aplikasi kasir portabel ini adalah terpadunya semua transaksi dan administrasi yang tersistem dengan baik seperti laporan harian pada aplikasi kasir sehingga saat pelaporan rugi laba dapat terkoordinasi dengan baik dan keluaran / report dari aplikasi kasir portabel ini adalah laporan rugi laba baik itu laporan harian sampai dengan laporan bulanan dan tahunan untuk evaluasi keuntungan usaha dari kedai sari kopi.

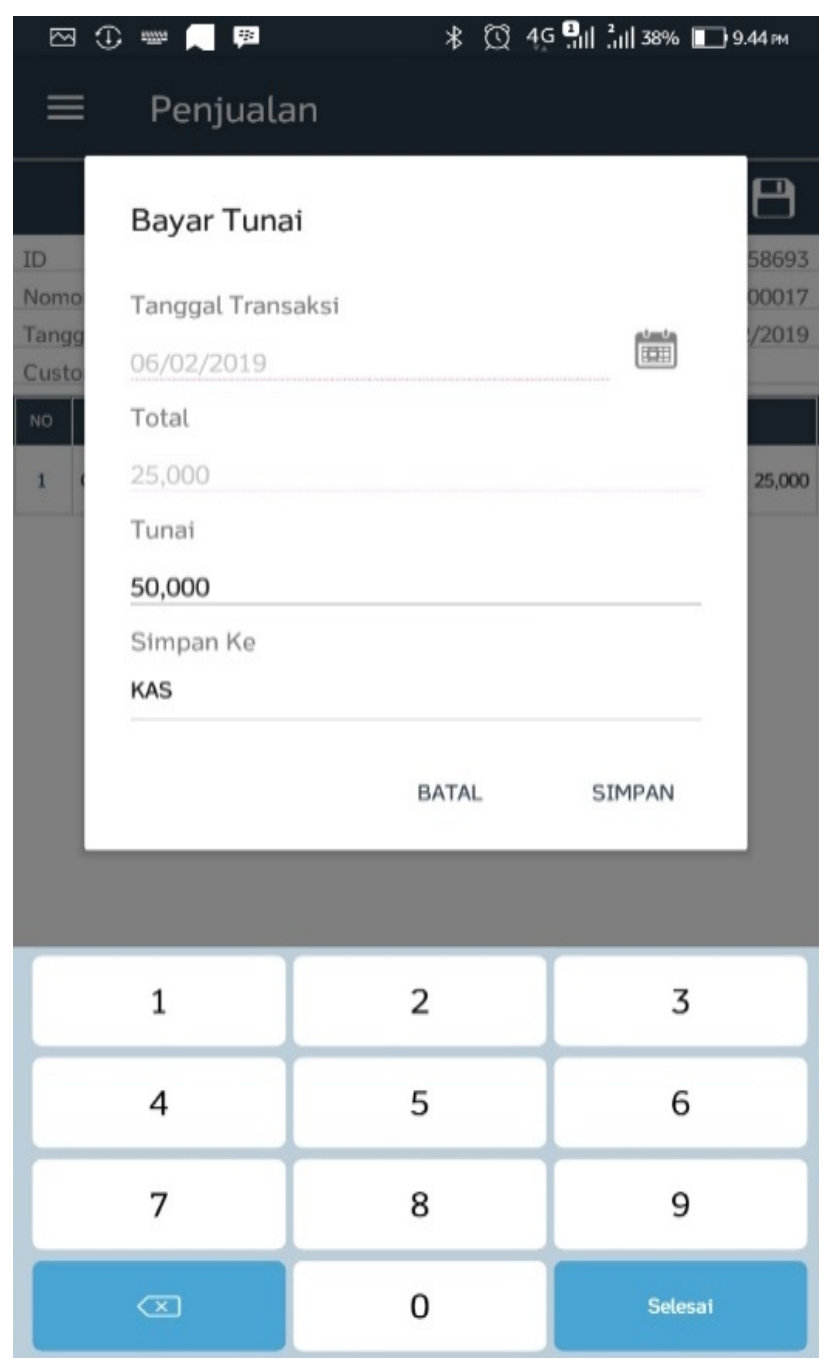

Gambar 8. Report Harian

Berdasarkan hasil uji coba terhadap aplikasi kasir portabel semua berjalan sesuai dengan permintaan kedai sari kopi Banjarbaru yaitu berupa menu-menu dari kedai sari kopi , slip pembayaran yang menjadi report dari aplikasi kasir portabel dan laporan rugi laba harian, mingguan serta bulanan sebagai evaluasi keuntungan dan rugi di kedai sari kopi Banjarbaru.

\section{Kesimpulan}

Tahapan kegiatan pengabdian yang dilaksanakan adalah sebagai berikut:

a. Kasir dan karyawan yang ikut serta pelatihan berperan aktif dalam proses pelatihan, instalasi dan tahapan evaluasi penggunaan aplikasi.

b. Kasir memahami proses penggunaan aplikasi untuk melakukan proses pelaporan rugi laba dan cetak nota penjualan yang merupakan bentuk keluaran atau report dari aplikasi kasir.

c. Karyawan memahami proses instalasi aplikasi dan penggunaan aplikasi yang akan memudahkan dalam pelayanan di kedai sari kopi.

Kesimpulan dari pelaksanaan pengabdian masyarakat berjalan dengan lancar dan sesuai dengan yang telah dijadwalkan dari tahapan pelatihan, instalasi, tahapan uji coba aplikasi dan evaluasi pelatihan serta penggunaan aplikasi.

\section{Ucapan Terima Kasih}

Tim Pengabdian Masyarakat mengucapkan terima kasih kepada seluruh tim di Kedai Sari Kopi karena telah bekerja sama dengan baik serta mengikuti dengan baik seluruh rangkaian kegiatan yang telah dijadwalkan oleh tim pengabdian kepada masyarakat.

\section{Daftar Pustaka}

[1] Hengky W. Pramana, (2012). Aplikasi Inventory Berbasis Access 2003.PT. Elex Media Komputindo, Jakarta.

[2] Indah, I. N. (2013). Pembuatan Sistem Informasi Penjualan Pada Toko Sehat Jaya Elektronik Pacitan. Speed-Sentra Penelitian Engineering dan Edukasi, 12(1).

[3] Kubo, J., Shuttleworth, M., Tokumura, N., \& Lee, S. (1999). U.S. Patent No. 5,889,676. Washington, DC: U.S. Patent and Trademark Office.

[4] Kuncoro, D. W. (2013). Analisis Dan Perancangan Sistem Kasir Dan Pendataan Stok Barang Pada Tata Distro Pacitan. Speed-Sentra Penelitian Engineering dan Edukasi, 12(1).

[5] Kamus besar Bahasa Indonesia ( www.kamusbesar.com), Selasa 7 Mei 2019 .1:36

[6] McLeod, R., \& Schell, G. (2004). Sistem informasi manajemen. Indeks. 
[7] Rokhman,A.,(2012). Apa itu software POS. [Online] Available http://abdulatifrokhman.com/2012/05/apa-itusoftware-pos/Stenley,I. (2009). Analisis kepuasan dan loyalitas konsumen coffeeshop warung kopi serta implikasinya terhadap strategi pemasaran.

[8] Stenley, I. (2009). Analisis kepuasan dan loyalitas konsumen coffeeshop warung kopi serta implikasinya terhadap strategi pemasaran.

[9] Sutabri, T. (2012). Analisis sistem informasi. Penerbit Andi. 